\title{
Effects of Heat Stress on Phytopigments of Zooxanthellae (Symbiodinium spp.) Symbiotic with the Corals Acropora hyacinthus, Porites solida, and Favites complanata
}

\author{
Kevin B. Strychar (Corresponding author) \\ Texas A \& M University - Corpus Christi \\ Department of Life Sciences, Corpus Christi, Texas 78412, USA \\ Tel: 1-361-825-5883 E-mail: kevin.strychar@tamucc.edu
}

Paul W. Sammarco

Louisiana Universities Marine Consortium (LUMCON)

8124 Hwy. 56, Chauvin, LA 70344, USA

Tel: 1-985-851-2876 E-mail: psammarco@lumcon.edu

Received: October 31, $2011 \quad$ Accepted: November 16, $2011 \quad$ Published: January 1, 2012

doi:10.5539/ijb.v4n1p3

URL: http://dx.doi.org/10.5539/ijb.v4n1p3

\begin{abstract}
The question of whether global warming affects phytopigments within Symbiodinium spp. of coral is central to understanding the process of coral bleaching. In this study, corals Acropora hyacinthus, Porites solida, and Favites complanata were exposed to elevated temperatures $\left(28,30,32\right.$, and $\left.34^{\circ} \mathrm{C}\right)$ for $48 \mathrm{~h}$ and the responses of Symbiodinium chl a, chl c, total carotenoids, total phaeophytins, and fucoxanthins were examined. In $A$. hyacinthus, the phytopigment concentrations at 28 and $30^{\circ} \mathrm{C}$ were significantly different from 32 and $34^{\circ} \mathrm{C}$, implying a step-function response initiated between 30 and $32^{\circ} \mathrm{C}$. In P. solida, all phytopigments varied significantly between the temperatures, except in the case of total carotenoids which had no significant response. In $F$. complanata, all phytopigments decreased linearly as temperature increased. Our results indicate that decreases in Symbiodinium phytopigments in response to heat stress may be a need to adapt while their host coral may already be adapted (or exapted).
\end{abstract}

Keywords: Carotenoids, Chlorophyll a (chl a), Chlorophyll c (chl c), Coral bleaching, Fucoxanthins, Global warming, Phytopigments, Phaeopigments

\section{Introduction}

In scleractinian corals containing endosymbiotic zooxanthellae, loss of coloration (or bleaching) is due to the loss of the dinoflagellates (Symbiodinium spp.) and their associated pigments (Venn et al., 2006). Some corals contain light-absorbing pigments (Shibata, 1969), including fluorescent chromoproteins (Salih et al., 2000, 2006; Dove et al., 2006; Riddle, 2009). In this paper, however, only the phyopigments of the endosymbiotic zooxanthellae of hermatypic corals will be considered.

The loss of phytopigments results in decreased photosynthesis and reduced production of symbiont photosynthate, which can in turn contribute to death of the host (see Salih et al., 2000). Phytopigments also provide the host with ultraviolet radiation (UVR) protection and color as a physical trait (Salih et al., 2000, 2006; Dove et al., 2006; Banaszak \& Lesser, 2009). Studies examining the effects of elevated temperature on the phytopigments of Symbiodinium cells in scleractinian corals are equivocal. Flores-Ramírez and Liñán-Cabello (2007), for example, have shown increased levels of chlorophyll a (chl a) and carotenoid pigments in the zooxanthellae of Pocillopora capitata as temperatures increased from 22 to $28^{\circ} \mathrm{C}$. Ralph et al. (2001) have reported that photosynthesis in expelled zooxanthellae from Cyphastrea serailia and Pocillopora damicornis is fully functional, although they do not report the zooxanthellar clade(s) in the holobiont coral. Some studies, however, indicate that phytopigment concentrations decrease as temperatures increase (Jokiel \& Coles, 1974; Kleppel et al., 1989; Jones et al., 1998; Fitt et al., 2000). Others offer evidence that chlorophyll concentrations in 
zooxanthellae remain unchanged under elevated seawater temperature conditions (Hoegh-Guldberg and Smith 1989a, 1989b). Thus, previous experimentation has not yielded clear results regarding whether phytopigment concentrations of Symbiodinium increase, decrease, or remain stable during temperature increases.

Jokiel and Coles (1974) and Coles and Jokiel (1977) demonstrated that certain Indo-Pacific corals vary in their sensitivity to increasing seawater temperatures. Warner et al. (1999), Baker et al. (2004), Baker (2003, 2004), and Lajeunesse et al. (2004) have also shown that some species of Symbiodinium exhibit optimum growth and phytopigment synthesis rates between 26 to $32^{\circ} \mathrm{C}$. Other species function best at $26^{\circ} \mathrm{C}$, poorly at $30^{\circ} \mathrm{C}$, and cease to function at all at $32^{\circ} \mathrm{C}$ (Warner et al., 1999). More recently, Venn et al. (2006) documented a 50-80\% loss of symbiont cells in Montastrea cavernosa at $32^{\circ} \mathrm{C}$, but observed no significant pigment loss (chl a and peridinin) concentrations in retained cells. These authors also reported, however, a substantial loss of chl a and carotenoids at $32^{\circ} \mathrm{C}$ but no loss of Agaricia sp. symbiont cells. The maximum temperatures at which a symbiont and its associated pigments can function, then, defines the upper limit of the range within which the host coral can receive nutrients from their symbionts. The question arises as to whether the pigments involved in photosynthesis play a key role for the survival or mortality of Symbiodinium and the host under conditions of increased temperatures (Fitt et al., 1993; Apprill et al., 2007). Hoegh-Guldberg and Smith (1989b) observed increases in pigment concentrations within Seriatopora hystrix during bleaching on the Great Barrier Reef, despite decreases in Symbiodinium populations. By contrast, Dove et al. (2006) have reported decreased pigment concentrations without a significant loss of zooxanthellae.

Although chl a is the primary phytopigment responsible for photosynthesis in zooxanthellae, secondary pigments such as chlorophyll c (chl c) and carotenoids absorb light energy that chl a does not (Govindjee and Govindjee, 1974; Chalker and Dunlap, 1982). Carotenoids have two primary functions in photosynthesis: 1) the capture of light energy and transfer of that energy to chlorophyl molecules to be used for photochemical reactions (Ston and Kosakowska, 2000); and 2) photo-protection of reaction centers, cells, tissues, and pigment-protein antennae (Demming et al., 1987; Gilmore et al., 1995; Demming-Adams et al., 1996; Porra et al., 1997; Mobley and Gleason, 2003). They operate within the PS-I system and consist predominantly of carotenes. Those operating within the PS-II system primarily contain xanthophylls (Govindjee, 1975). Symbiodinium spp. are dinoflagellates which belong to the Peridiniales. This order contains a variety of xanthophylls. Symbiodinium is known to contain a relatively small amount of the accessory pigment fucoxanthin, representing one of the phytopigments we considered here. Zhang et al. (2005) have found through genetic analyses that the taxonomy of Symbiodinium is not clear as to whether it falls within the peridin lineage or some other. Phaeophorbides and phaeophytins are the principal degradation products of chl a. Such phaeopigments, when present, indicate algal senescence, decay, or autolysis (Govindjee, 1975).

Phytopigments are known to be susceptible to elevated temperatures (e.g., Thebud \& Santarius, 1982), and PS-II appears to be the more sensitive of the two photosynthetic systems (Becker et al., 1990; Havaux, 1993). It is not yet known whether heat stress causes a decrease in the functional ability of phytopigments in Symbiodinium, causing degeneration of the carotenoids and thus disrupting the PS-I and -II systems (Warner et al., 1996). There has also been some recent interest in characterizing degradation of pigment systems due to temperature stress in the symbionts of scleractinian corals, particularly with respect to chl a (Fang et al., 1995; Brown et al., 1999; Mobley and Gleason, 2003; Smith et al., 2005; Hill and Ralph, 2006; Liñán-Cabello et al., 2006; Flores-Ramírez \& Liñán-Cabello, 2007; Cooper \& Fabricius, 2011). Information is needed on the mechanism by which heat stress affects multiple pigments other than chl a, in order to increase our understanding of susceptibility of zooxanthellae to bleaching. In addition, this information is needed from several species of corals drawn from different families within the Scleractinia, in order to determine whether the responses of phytopigments to heat stress vary inter-specifically or not.

In this study, we examine the effects of heat stress on various phytopigments of Symbiodinium within three scleractinian coral hosts - Acropora hyacinthus, Porites solida, and Favites complanata - representing the families Acroporidae, Poritidae, and Faviidae. We do this in order to gain a deeper understanding of the bleaching mechanism under varying temperatures, and to elucidate both species-specific and phytopigment-specific responses.

\section{Materials and Methods}

\subsection{Experimental design}

The experiment followed a two-way, balanced, mixed model, 3-level nested, balanced, orthogonal design (see Sokal \& Rohlf, 1981; McKillup, 2006). The first factor (fixed) was scleractinian corals, of which there were three species - Acropora hyacinthus, Porites solida, and Favites complanata, derived from three different 
families - the Acroporidae, the Poritidae, and the Faviidae. Replications were represented by trials of the experiment, of which there were five (5) in temporal sequence in contiguous 48-h periods, nested within species. This trial duration was chosen because this is the minimum amount of time required to induce bleaching in corals when exposed to increased temperatures (Strychar et al., 2004b; 2005).

The second factor (fixed) was the experimental temperatures of $28,30,32$, and $34^{\circ} \mathrm{C}$. Two replicate tanks were nested within each temperature treatment. Two (2) incubation chambers were used for each temperature treatment, one in each tank. Each one of those chambers received two (2) coral fragments. The total number of replicates per temperature treatment within any given trial was 10 . The total number of coral samples used per species was 80 (4 temperatures $\times 2$ replicates/tank $\times 5$ trials/temperature), each $\sim 100 \mathrm{~g}$ in weight. A total of 20 coral fragments were exposed to each experimental treatment/temperature. Data on phytopigment concentrations from the two corals in a given chamber per trial were averaged. Thus, an experimental replicate is defined by the number of incubation chambers, not the number of corals in each chamber; (i.e., "n" $=10$ not 20). This provided a more conservative approach to data analysis. It should be noted that any given coral fragment was only used in the experiment once.

\subsection{Experimental set-up}

Corals were collected from the Capricorn Bunker Reefs of Barren Island $\left(23^{\circ} 10^{\prime} \mathrm{S}, 151^{\circ} 55^{\prime} \mathrm{E}\right)$ and Outer Rocks $\left(23^{\circ} 4^{\prime} \mathrm{S}, 151^{\circ} 57.2^{\prime} \mathrm{E}\right)$, Queensland, Australia. Coral fragments were collected by SCUBA divers at 7-10 $\mathrm{m}$ using pliers or a hammer and chisel. Collected fragments were placed separately into plastic containers and sealed at depth, and transported via divers to the surface. The plastic containers were placed into temperature-controlled coolers containing seawater, held on the dive boat. The holding containers were then opened to allow water exchange to occur; $75 \%$ of the sea water was replaced every two hours. The corals were then transported to the laboratory at Central Queensland University (Australia) and placed in a $200 \mathrm{~L}$ holding tank containing 1 $\mu \mathrm{m}$-filtered seawater, derived from near-shore waters in the region. All corals were subjected to a 12:12 $\mathrm{h}$ day:night light regime $\left(150 \mu \mathrm{E} \mathrm{m}^{-2} \mathrm{~s}^{-1}\right)$.

The control temperature used in these experiments was $28^{\circ} \mathrm{C}$, the mean maximum weekly sea surface temperature (SST) from 1981 to 2001 (Reynolds and Smith, 1994). Coral fragments that were acclimated to this temperature for $>4$ months exhibited no symptoms of bleaching stress. In addition, skeletal areas on the coral fragments that had been damaged during collection healed over during this acclimation period.

The experimental variable-temperature tanks have been described in detail in Strychar et al. (2004b), but will be briefly described here. Sea water was collected from the coast ( $\sim 30 \mathrm{~km}$ from where the corals were collected), transported, and then pumped into an enclosed 4,000 L storage tank. The sea water was then pumped through 10 $\mu \mathrm{m}$ and $1 \mu \mathrm{m}$ filters at a constant flow rate of $20 \mathrm{ml} \mathrm{min}^{-1}$, through Tygon tubing to a series of plastic incubation containers. Each incubation chamber contained an incurrent and excurrent pipe that regulated filtered seawater levels to a volume of $1.5 \mathrm{~L}$. Water within each holding container was mixed with an octagon-shaped Teflon "spin-wedge ${ }^{\circledR, " ~(C r o w n ~ S c i e n t i f i c ~ L t d .) ~ s t i r ~ b a r, ~ s p u n ~ b y ~ a ~ m a g n e t i c ~ s t i r r e r . ~ S a l i n i t y ~ c o n c e n t r a t i o n s ~ w e r e ~ m o n i t o r e d ~}$ every $12 \mathrm{~h}$ with a TPS WP-84 conductivity-salinity meter. Temperatures within each holding chamber were maintained using $125 \mathrm{~W}$ Jäger $^{\circledR}$ (Aquacenta Ltd.) aquarium heaters.

Corals were subjected to seawater heated to 30,32 , or $34^{\circ} \mathrm{C}$ and compared to a control at $28^{\circ} \mathrm{C}$. Temperatures within each chamber were monitored every 15 min with submersible digital data-loggers (Tiny-tags ${ }^{\mathbb{B}}$; Hastings Data Loggers) placed at the bottom of each holding container. Mercury-filled thermometers, accurate to $0.1{ }^{\circ} \mathrm{C}$, were also used to help identify water temperature fluctuations in each holding container. If the water temperature fluctuated more than $0.5^{\circ} \mathrm{C}$, the aquarium heaters were re-adjusted. The rates of temperature increase and the duration of exposure used in this experiment are probably faster and shorter than those that might occur naturally prior to, and during, a bleaching event in the field. Thus, any change in zooxanthellar phytopigment concentrations oberved here might be considered an underestimate of that which might be observed over longer periods of time.

Lighting for all experiments consisted of two $10,000 \mathrm{~K}$ and one $7,500 \mathrm{~K}$ actinic fluorescent lights, mimicking diurnal patterns of $12 \mathrm{~h}$ light: $12 \mathrm{~h}$ dark and a level of irradiance consistent with both the holding tank and the conditions at depth in the field $\left(\sim 150 \mu \mathrm{E} \mathrm{m}^{-2} \mathrm{~s}^{-1}\right)$. Light levels were monitored every $6 \mathrm{~h}$ with a Li-Cor 250 Quantum photometer.

\subsection{Phytopigment analysis of symbiont Symbiodinium spp. collected from each coral}

Symbiont pigments included the following five phytopigments: chlorophyll a (chl a), chlorophyll c (chl c), total carotenoids, total phaeophytins, and fucoxanthins. Approximately $5 \mathrm{ml}$ of coral tissue were water-picked off of the 
coral skeletons, which greatly reduced if not eliminated contamination by Ostreobium sp. and other endolithic algae (Agustin, 2007). The collected tissue slurry was re-suspended in filtered seawater to create a $10 \mathrm{ml}$ sample (final volume), and homogenized with an Ultra Turrax T-25 at low speed; homogenization enhances the rupture of algal cells and increases the extraction efficiency of acetone (Sartory \& Grobbelaar, 1984). The tissue homogenate was then filtered through Whatman GF/C glass fibre filters. Marker et al. (1980) reported that Whatman GF/C filters are better than membrane filters because they efficiently retain chlorophyll. Each filter was cut into small pieces, resuspended into $10 \mathrm{~mL}$ of $90 \%$ acetone, and homogenized for $1 \mathrm{~min}$ at low speed (Jones, 1997). Acetone was used as the extraction solvent, since Mantoura and Llewellyn (1983) found that methanol solvents lead to derivative products from chl a. Extracts of phytopigments were kept in the dark at $-20^{\circ} \mathrm{C}$ for a minimum of $24 \mathrm{~h}$ following the methods Lenz and Fritsche (1980). This was done in order to reduce pigment degradation due to the death and decomposition of zooxanthellar cells. Thawed extracts were then centrifuged at $1000 \times g$ for 5 min to remove filter fibers and algal debris. Phytopigment absorbances were read on a Perkin Elmer UV/VIS Lambda Bio 20 spectrophotometer.

The methods used here to extract the pigments followed Jeffrey and Humphrey (1975), American Public Health Association (APHA, 1989), and those of Leletka and Popova (2005). No attempt was made to describe or quantify pigment breakdown. We focused entirely on changes in Symbiodinium pigment concentrations, standardized by number of zooxanthellar cells present in situ, in response to elevated temperature. All phytopigment concentrations isolated from symbiont cells are expressed in terms of picograms per cell ( $\mathrm{pg} \mathrm{cell}^{-1}$ ), following Hoegh-Guldberg and Smith (1989), and Jones (1997); changes in cell densities with respect to experimental temperature changes may be found in Strychar et al., 2004a. Data corresponding to each experimentally tested coral was collected at the beginning and at the conclusion of each experiment to help determine the total number of Symbiodinium present. At each sampling interval, the number of Symbiodinium present was determined following methods described in Strychar et al. (2004a). Briefly, the number of in situ live + dead + mitotic Symbiodinium cells were enumerated using a hemocytometer (replicate counts, $\mathrm{n}=10$ ) and a light microscope, and expressed per unit volume of extracted coral tissue ( $1 \mathrm{~g}$ in $1 \mathrm{~mL}$ of filtered sea-water). For comparative purposes, tissue was also removed from other replicate corals that were not used in the experiments.

We recognize that HPLC (high pressure liquid chromatography) is the best method to examine pigment concentrations; however, we neither had access to nor the resources to use this instrument. Latasa et al. (1996) report that absorption techniques using spectrophotometric analyses produce historically accurate and comparative data when pigments are stored in the dark and at $-20^{\circ} \mathrm{C}$. Comparative analyses of three separate labs using HPLC vs. spectrophotometry in their study yielded generally comparable pigment concentration data. The spectrophotometry data was more precise than the HPLC data, in that the authors observed a range variation of $\pm 6 \%$ between the different labs using this technique vs. HPLC data, which exhibited a $\pm 10 \%$ to $\pm 20 \%$ range of variability. Brotas et al. (2007) concluded that chlorophyll spectrophotometric analyses are reliable, but that HPLC is indispensable when available and provides greater accuracy and a higher level of resolution. Here, the statistical comparisons between treatments were significantly different, indicating that the observed responses were robust.

Samples were examined for phytopigment concentrations of chl a and chl $\mathrm{c}$ using light wavelengths of $664 \mathrm{~nm}$ and $630 \mathrm{~nm}$, corrected by subtracting the absorbance value at $750 \mathrm{~nm}$, as specified by Arar (1997). Following this author's recommendations, equations used for specific pigments are:

(1). chl a $=11.85 \times[($ Abs $664 \mathrm{~nm}-$ Abs $750 \mathrm{~nm})-0.08 \times($ Abs $630 \mathrm{~nm}-$ Abs $750 \mathrm{~nm})]$;

(2). $\mathrm{chl} \mathrm{c}=24.52 \times[($ Abs $630 \mathrm{~nm}-\mathrm{Abs} 750 \mathrm{~nm})-1.67 \times($ Abs $664 \mathrm{~nm}-\mathrm{Abs} 750 \mathrm{~nm})]$;

(3). Carotenoid concentrations (C-car) C-car $=7.6 \times[($ Abs $480 \mathrm{~nm}-$ Abs $750 \mathrm{~nm})-(1.49 \times\{$ Abs $510 \mathrm{~nm}-$ Abs750 nm $\})$ ];

(4). Phaeophytin concentrations $=26.7 \times\left[1.7 \times\left(\left(\mathrm{Abs}_{\mathrm{a}} 665 \mathrm{~nm}-\mathrm{Abs}_{\mathrm{a}} 750 \mathrm{~nm}\right)-\left(\mathrm{Abs}_{\mathrm{b}} 664 \mathrm{~nm}-\mathrm{Abs}_{\mathrm{b}} 750 \mathrm{~nm}\right)\right]\right.$;

(5). Fucoxanthin concentrations $=[$ Abs $470 \mathrm{~nm}-1.239($ Abs $631 \mathrm{~nm}+$ Abs $581 \mathrm{~nm}-(0.3 \times$ Abs $664 \mathrm{~nm})-$ $(0.0275 \times$ Abs $664 \mathrm{~nm})] / 141$

Carotene is one of the pigments that passes its absorbed energy to chlorophyll when exposed to light. Here we ask whether carotenoids as a whole respond differently than other pigment groups upon exposure to increased seawater temperatures (Agustin, 2007). This approach of using carotenoids as a group to examine phytopigment changes during the bleaching process has been successfully used by Liñán-Cabello et al. (2006) on corals from the Pacific coast of Mexico. Analysis to determine phaeophytin concentrations was performed before and after the addition of 3 drops of $1 \mathrm{M} \mathrm{HCl} \mathrm{ml}^{-1}$ of extract (Arar, 1997). In the above equation referring to phaeophytins, $\mathrm{Abs}=$ absorbance, $\mathrm{Abs}_{\mathrm{a}}=$ absorbance after acidification, and $\mathrm{Abs}_{\mathrm{b}}=$ absorbance before acidification. Techniques 
used to examine fucoxanthin concentrations did not have a correction factor for carotenoid absorption, which could potentially lead to a liberal estimate of fucoxanthins (Seely et al., 1972). Thus, these calculations were corrected for carotenes by subtracting the total amount of carotenoids derived from equation 3 .

\subsection{Statistical analysis}

Pigment data were tested for heteroscedasticity prior to analysis. Data found to be heteroscedastic were log-transformed for normalization purposes and then analysed by ANOVA and linear and polynomial regression, using SigmaPlot V 8.0, BiomStat V3.2, and SPSS. Percent data were arcsine-transformed prior to analysis for purposes of normalization. Data found to be significantly different were further tested via T', T-K, and GT2 a posterior multiple comparisons of means analyses; these were used to identify specific treatments contributing to the observed significance. Only significant linear and curvilinear regression lines are shown in figures. Details of statistical results are presented in the text and in figure and table legends.

\section{Results}

\subsection{Overall comparisons}

An overall analysis of the chl a data via a 2-way nested ANOVA revealed that there was a highly significant difference between endosymbiont phytopigment concentrations between coral species $(p<0.001$, two-way nested ANOVA) and between temperatures $(\mathrm{p}<0.01)$. There was also a significant interaction between species and temperature $(\mathrm{p}<0.01)$, indicating that zooxanthellar phytopigments of different coral species did not respond similarly to temperature changes in all cases. There was also a significant difference between tanks $(\mathrm{p}<0.05)$.

\subsection{Symbiodinium phytopigment responses in Acropora hyacinthus}

The absolute concentrations of all pigments were within the same range as those observed in Symbiodinium from Acropora hyacinthus. In A. hyacinthus, Symbiodinium chl a concentrations dropped significantly as temperature increased ( $\mathrm{p}<0.01$, two-way ANOVA). Colonies held at 32 and $34^{\circ} \mathrm{C}$ had significantly lower Symbiodinium chl a concentrations than those at lower temperatures, i.e. 28 and $30^{\circ} \mathrm{C}(\mathrm{p}<0.05, \mathrm{~T}, \mathrm{~T}-\mathrm{K}$, and GT2 a a posteriori multiple comparisons tests between means; Figure 1). This same general pattern occurred in chl c, fucoxanthins, total carotenoids, and total phaeophytins $(\mathrm{p}<0.001$, two-way ANOVA; $\mathrm{p}<0.05$, a posterior multiple comparisons tests); Figure 1). This difference was pronounced in all pigments tested, when comparing the $28^{\circ} \mathrm{C}$ vs. $34^{\circ} \mathrm{C}$ treatments $(\mathrm{p}<0.001$, Tukey test). The decrease in total carotenoid concentration decreased in a significantly linear manner in response to increasing seawater temperatures $(\mathrm{p}<0.05$, linear regression analysis).

\subsection{Symbiodinium phytopigment responses in Porites solida}

Concentrations of Symbiodinium chl a associated with Porites solida exhibited differences similar to those observed in A. hyacinthus as seawater temperatures were increased $(\mathrm{p}<0.001$, ANOVA; Figure 2). That is, responses at $28^{\circ} \mathrm{C}$ and $30^{\circ} \mathrm{C}$ were significantly different from responses at $32^{\circ} \mathrm{C}$ and $34^{\circ} \mathrm{C}(\mathrm{p}<0.05$, a posteriori tests - as above). In chl $\mathrm{c}$ and in the fucoxanthins, concentrations were significantly different between temperature treatments $(\mathrm{p}<0.001$ and 0.05 , respectively, ANOVA). The concentrations of chl c were significantly lower under the $34^{\circ} \mathrm{C}$ treatment than under all other temperatures, including the control $(\mathrm{p}<0.05, a$ posteriori tests), resulting in a significant curvilinear relationship between chl c concentration and temperataure despite the small number of $X$-values used in the analysis $(\mathrm{p}<0.001$, polynomial least squares regression analysis; Figure 2). The peak in the curve occurred at $30^{\circ} \mathrm{C}$. There was no significant difference between zooxanthellar carotenoids under the different temperature treatments ( $>0.05$, ANOVA); the variances of the individual means were large enough to obscure any significant trends that might have been present. Zooxanthellar phaeophytin concentrations were significantly different between treatments ( $<<0.001$, ANOVA). Significant differences were detected between individual temperature treatments in both the fucoxanthins and total phaeophytins ( $\mathrm{p}<0.05$, a posteriori tests). Test results were complex enough, however, to not yield any clear trends, due to high variances in the data.

Initial concentrations of all Symbiodinium pigments were lower in P. solida than in A. hyacinthus, as was the overall intensity of negative responses to increases in seawater temperature. For example, in $P$. solida, Symbiodinium chl c concentrations decreased from $0.4 \mathrm{pg}^{-1}$ cell $^{-1}$ to $0.2 \mathrm{pg}$ cell $^{-1}$, or by $50 \%$, while chl c Symbiodinium concentrations in A. hyacinthus decreased from $0.7 \mathrm{pg} \mathrm{cell}^{-1}$ to $0.2 \mathrm{pg}^{-1} \mathrm{cel}^{-1}$ or by $70 \%$.

\subsection{Symbiodinium phytopigment responses in Favites complanata}

In Favites complanata, chl a, chl c, fucoxanthin, and carotenoid concentrations varied significantly between all experimental temperatures $(\mathrm{p}<0.05-0.01$, ANOVA). In this coral species, however, Symbiodinium pigment concentrations decreased significantly in a linear fashion in all zooxanthellar phytopigments as seawater 
temperatures increased ( $\mathrm{p}<0.05-0.01$, linear regression analyses; Figure 3). Chl a of Symbiodinium in this coral species decreased significantly and linearly from about 0.9 to $0.5 \mathrm{pg}^{\text {cell }}{ }^{-1}$ as temperature increased $(\mathrm{p}<0.05$, linear regression analysis).

A posteriori tests detected significant differences between experimental temperatures in Symbiodinium concentrations of chl a, chl c, total fucoxanthins, and total carotenoids ( $<<0.05, \mathrm{~T}$, T-K, and GT2 tests). Specific differences between temperatures, however, were not clear; comparisons of individual temperatures often overlapped in homogeneity in their groupings. Thus, they will not be discussed any further. Total Symbiodinium phaeophytin concentrations in $F$. complanata were not different enough between temperature treatments to be detected by ANOVA $(p>0.05)$. This was most likely due to high variance associated with the individual means (Figure 3). The decrease in phaeophytin concentrations was clear enough, however, to be detected by least squares linear regression $(\mathrm{p}<0.05)$.

\subsection{Overall comparisons}

Considering comparisons of overall concentrations of zooxanthellar phytopigments, there was a highly significant difference in total Symbiodinium pigment concentrations between experimental seawater temperatures $(\mathrm{p}<0.001$, three-way ANOVA). In addition, significantly different concentrations were found between the five sets of Symbiodinium pigments examined here ( $\mathrm{p}<0.01$, three-way ANOVA). Specific changes will be discussed below, but in general, a posteriori tests revealed that Symbiodinium from A. hyacinthus had higher concentrations of pigments than Symbiodinium from either $P$. solida and $F$. complanata. Symbiodinium $\mathrm{Chl}$ a concentrations were significantly higher in the coral A. hyancinthus than in $P$. solida at $28^{\circ} \mathrm{C}(\mathrm{p}<0.05$, Tukey tests). Symbiodinium chl c concentrations also varied significantly between these two coral species at $32^{\circ} \mathrm{C}(\mathrm{p}<0.05)$. Symbiodinium fucoxanthin concentrations were found to be significantly different between these two coral species, but this time at $28^{\circ} \mathrm{C}(\mathrm{p}<0.01)$. Concentrations of Symbiodinium phaeophytins were homogeneous between all coral species at all temperatures measured here $(\mathrm{p}>0.05)$. Symbiodinium pigment concentrations from $F$. complanata were also comparable to those observed from $A$. hyancinthus and Porites solida $(\mathrm{p}>0.05)$.

Overall patterns indicate that Symbiodinium from A. hyacinthus was the most sensitive to elevated seawater temperatures with respect to changes in pigment concentration; that is, these algal symbionts exhibited the highest proportional drop with respect to mean concentration of pigment (Figure 4). All Symbiodinium pigment concentrations in this coral species decreased by $74-77 \%$ between 28 and $34^{\circ} \mathrm{C}$. Symbiodinium derived from Favites complanata was the next most sensitive, with its pigment concentrations dropping by $45-60 \%$. Symbiodinium from Porites solida was the least sensitive; its pigment concentrations dropped by $23-64 \%$. These values were highly dependent upon the particular symbiont pigment under consideration, with total phaeophytins exhibiting the highest rate of reduction and total carotenoids the lowest.

\section{Discussion}

Changes in zooxanthellar phytopigment concentration in corals may be used as an indicator of bleaching and stress within $48 \mathrm{~h}$ of their exposure to elevated seawater temperatures. These declines in concentration are most likely conservative estimates of those that might occur in the field under natural conditions of prolonged increased seawater temperatures. That is, the holobiont may be expected to be exposed for a much longer time period. Kleppel et al. (1989) observed loss of symbiont pigments during a natural bleaching event off south-east Florida, which accounted for a decrease of $\sim 72 \%$ of chl $\mathrm{c}$ in the coral Montastraea annularis. Within $48 \mathrm{~h}$ in our study, decreases in concentrations were observed in all symbiont pigments considered and in all three coral species tested.

These species were derived from three different families of Scleractinia. This indicates a general response or sensitivity among zooxanthellae that are symbiotic within the families Acroporidae, Poritidae and Faviidae from the Great Barrier Reef region. Ralph et al. (2001) found that the zooxanthellae in Pocillopora damicornis are highly resistant to seawater temperature increases, even after expelled. Hoegh-Guldberg and Smith (1989) observed little to no changes in Symbiodinium chl a concentrations in Stylophora pistillata when exposed to elevated temperatures of 27 to $32^{\circ} \mathrm{C}$. Both of these species are pocilloporids. Unfortunately, we did not investigate any pocilloporid species; therefore, no direct comparison may be made, although this implies that endosymbionts of pocilloporids may be more temperature-tolerant than in our species. On the other hand, they found similar results with Cyphastrea serailia, a faviid. This indicates that there is some variance in phytopigment sensitivity to increased seawater temperatures within the Faviidae.

Our results also suggest that as symbiont photosynthetic ability decreases, the level of nutrients passed from zooxanthellae to the host will also decrease (see Abrego et al., 2008). Li et al. (1984) and Jones et al. (1998) 
observed decreased carbon fixation when photosynthesis of their symbionts decreased. The levels of change in Symbiodinium phytopigment concentration vary inter-specifically. The temperatures considered here are similar to those proposed to occur under projected climate change conditions (Goenaga et al., 1989; Schlichter, 1990). The change in Symbiodinium pigment concentrations observed in this experiment may have been due to: a) zooxanthellae being lost from the host coral; or b) the pigments degrading within the symbiont cells, while algae were being retained by the host.

The observed decline in symbiont pigment concentration at $32^{\circ} \mathrm{C}$ in our study suggests that elevated temperatures (e.g. $\geq 32^{\circ} \mathrm{C}$ ) cannot be tolerated by Symbiodinium, even for short periods of time. At $34^{\circ} \mathrm{C}$, the symbiont pigments probably became dysfunctional (Warner et al., 1999; Agustin et al., 2006) and began to degrade (Demming-Adams et al., 1996; Hendry and Price, 1993). This agrees with the earlier results of Warner et al. (1996) who observed that the greatest variation in Symbiodinium pigment concentration in Agaricia agaricites and Siderastrea radians occurs when temperatures are increased from 30 to $32^{\circ} \mathrm{C}$ (experimental temperature range: 30 to $36^{\circ} \mathrm{C}$ ). Hoegh-Guldberg and Smith (1989) also reported changes in Symbiodinium pigment concentrations in Seriatopora hystrix. These authors show symbiont chl a concentrations decreasing from $\sim 4.5 \mathrm{pg}$ cell $^{-1}$ at $27^{\circ} \mathrm{C}$ to $3 \mathrm{pg}$ cell $^{-1}$ at $30^{\circ} \mathrm{C}$ when exposed to such temperatures over 4 days, but the drop was apparently not significant due to high variances in the data. Our changes, however, represent significant drops in Symbiodinium chl a concentration at $32^{\circ} \mathrm{C}$. We hypothesize that the symbiont photosynthetic pathway probably remains intact, at least partially, at temperatures $\leq 30^{\circ} \mathrm{C}$.

One of the reasons why we may have observed interspecific variation in responses of the phytopigment concentrations to increased seawater temperature is that the corals harbor different clades. Firstly, we have demonstrated that these corals possess Symbiodinium clades b and c. Clade b only occurs in Acropora hyacinthus, while clade c occurs in all of these species (Strychar et al., 2005; also see Sammarco \& Strychar, 2009). It would appear that differential responses of phytopigment concentrations observed between Favites complanata and Porites solida may be due to varying complements or relative abundances of sub-clades of clade c. On the other hand, the high pigment losses observed in A. hyacinthus may be due to the presence of clade b, which may in turn be less tolerant of high temperatures than clade c. Thus, higher rates of pigment loss would have resulted. This question remains open.

Responses of Symbiodinium phytopigment concentration to elevated seawater temperature varied greatly between coral species and between specific symbiont pigments. In general, Symbiodinium total phaeophytins appeared to be affected the most by elevated seawater temperatures, followed by chl c. Symbiodinium carotenoids were, on the whole, the least affected by temperature. Reese et al. (1988), however, found that carotenoids and chlorophyll concentrations in Symbiodinium from Montastraea annularis decreased by $81-97 \%$ in bleached corals vs. non-bleached corals. The contrast between the levels of response in Symbiodinium carotenoids in Reese et al.'s (1988) study $v s$. ours may be due to species-specific differences in endosymbiont physiological tolerances. Hoegh-Guldberg and Smith (1989) suggest that such inter-specific differences in symbiont response between different coral species may be due to an initial decline in both zooxanthellar pigment content and density. Mobley and Gleason (2003) suggest that carotenoid content in symbiotic anthozoans may increase by ingestion of carotenoid-rich zooplankton. It is also possible that the host may compensate for heat stress by drawing more heavily upon its stored lipids, which are characteristically high in carotenoid content (see Goodwin, 1980; Olsen \& Owens, 1998). We speculate that, under low temperature stress (e.g. 28 to $30^{\circ} \mathrm{C}$ ), the presence of Symbiodinium carotenoids, such as $\beta$-carotene, whether derived from symbiont production or from ingestion by the host, may ameliorate some of the deleterious effects of heat stress (Demmig-Adams and Adams, 2000). Peñuelas and Munné-Bosch (2005) have shown that carotenoids, including $\beta$-carotene, are antioxidants that act by dissipating excess reactive oxygen species and excitation energy in heat-stressed cells.

Chlorophyl a and chl c are pivotal to both the PS-I and -II photosystems (De Martino et al., 2000). Our data indicate that these two pigments were depleted in Symbiodinium under temperature stress. This supports the findings of Shenkar et al. (2006) who found a significant negative correlation between chl a concentrations, bacterial bleaching, and average seasonal SSTs, with a maximum observed drop of $92 \%$. Declines in concentrations of the other Symbiodinium pigments also impacts both of these photosystems, further inhibiting production of sugars within the zooxanthellae (Tchernov et al., 2004; Smith et al., 2005; Brüssow, 2007). If photosynthate production is compromised, then energy supplies may become limiting for both the endosymbiont and host cells, increasing stress and inducing necrosis (Strychar et al., 2005; Sammarco \& Strychar, 2009).

Acropora hyacinthus is known to be particularly susceptible to bleaching (Baird and Marshall, 2002; Strychar et al., 2004b; Wooldridge et al., 2005). It has been experimentally demonstrated that Symbiodinium cells are lost from this coral when temperatures are increased from 30 to $32^{\circ} \mathrm{C}$ (Marshall \& Baird, 2000; Strychar et al., 
2004b). In all pigments of Acropora hyacinthus, experimental increases in seawater temperature did not result in any significant decreases in pigment concentration until $32^{\circ} \mathrm{C}$. In fact, further a posteriori analyses revealed that responses of these pigments to temperature were the same between 28 and $30^{\circ} \mathrm{C}$ and also between 32 and $34^{\circ} \mathrm{C}$. This implies that the major sensitivity in this holobiont is occurring between $30^{\circ} \mathrm{C}$ and $32^{\circ} \mathrm{C}$, in concurrence with previous studies, and could be described as a step-function. Unfortunately, the experimental temperatures used here are insufficient to allow a detailed analysis; further studies are recommended.

It is not known precisely how much chl a is needed within each Symbiodinium cell to ensure survival. If one assumes that Symbiodinium survival is dependent upon the mean total chl a concentration measured at $28^{\circ} \mathrm{C}$ and $30^{\circ} \mathrm{C}$ - i.e., $2.6 \mathrm{pg} \mathrm{cell}^{-1}$ (A. hyacinthus; Figure 1), then the reduction of chl a to $\sim 0.8 \mathrm{pg} \mathrm{cell}^{-1}$ (average chl a concentration calculated from 32 and $34^{\circ} \mathrm{C}$ treatments) probably resulted in a drop in efficiency of the photochemical reactions within the symbiont. Thus, corals more heavily dependent on Symbiodinium as an energy source may be more susceptible to bleaching than other corals. The host coral can, however, survive severe bleaching events. Grottoli et al. (2006) have demonstrated that Montipora capitata can replenish its energy reserves and biomass by increasing its food intake five-fold after temperature-induced bleaching and the loss of its symbionts. Similarly, Ferrier-Pagés et al. (2010) studying heat-stressed Stylophora pistillata, Turbinaria reniformis, and Galaxea fascicularis, showed that these coral did not experience a decrease in their photosynthetic ability when fed. This helps to explain the results of Goreau and Goreau (1960) were able to keep some bleached corals alive in the dark for years by feeding them Artemia nauplii (also see Goreau and Goreau, 1959; Goreau et al., 1971; Pecheux, 1997). They believe that the cumulative effects of both thermal stress and starvation caused mortality. Leder et al. (1991) performed a similar experiment over a period of 10-12 mos with like results.

It is possible that a reduced flux of photosynthate from the symbiont to the coral host might be deleterious to the coral provoking the host's response. Kuguru et al. (2010), for example, observed host-cellular responses in corallimorpharians responding to zooxanthellae reducing their chlorophyll abundance as changes in irradiance occured. Here, only data on pigment concentrations per algal cell have been presented. It is therefore difficult to deduce the likely impact photosynthate changes have on the coral without having additional information on zooxanthellar pigment per unit area, a proxy for photosynthesis. Acropora hyacinthus has a relatively large standing stock of zooxanthellae (see Drew, 1972; Muscatine et al., 1989; Jones and Yellowlees, 1997) and was the most sensitive to increased seawater temperatures of all scleractinian corals with respect to apoptotic and necrotic responses as well as phytopigment concentrations. Yet Strychar (2002) and Strychar et al. (2004b) show that the standing stock of Symbiodinium in this and the other coral species is not correlated with inter-specific differences in heat tolerance. Hoegh-Guldberg and Smith (1989), working with Stylophora pistillata, concluded that increased seawater temperatures caused bleaching and a decrease in Symbiodinium pigment concentrations; these effects, however, were not associated with changes in the resident zooxanthellar population. This has also been shown to be the case with Montipora monasteriata (Dove et al., 2006). Of the corals studied here, Porites solida possessed zooxanthellae that were the most tolerant to elevated seawater temperatures, and the most resistant to bleaching (Strychar et al., 2004b; 2005). Photo-protective pigments are also produced by the host coral (Salih et al., 2000; 2006; Oswald et al., 2007; Riddle, 2007; Dove et al., 2008), and recent evidence suggests that these are also affected by elevated seawater temperatures (Lesser and Farrell, 2004).

Corals that were less prone to bleaching possessed more stable Symbiodinium carotenoid concentrations, and this conferred greater heat-stability on the PS-I and PS-II systems (Hill \& Ralph, 2006; Liñán-Cabello et al., 2006; Flores-Ramírez \& Liñán-Cabello, 2007). Jones et al. (1998) concluded that damage to the PS-I system has a greater impact on zooxanthellar photosynthesis than damage to the PS-II system. As was the case in Venn et al.'s (2006) study, the primary Symbiodinium carotenoids - carotenes (predominant within PS-I) and xanthophylls (predominant within PS-II; Govindjee, 1975) - could not be differentiated from each other here, due to equipment limitations. We do recommend, however, that these two pigments be considered separately in future studies to reveal more subtle changes due to temperature. These pigments may have separate functions in the organisms. For example, Barlow et al. (2007) describe different roles for carotenoids in smaller vs. larger plankton cells. In the former, the carotenoids function in photo-protection, while in the latter, they serve in photosynthesis. Carotenoids generally function to dissipate heat energy within PS-II system (Demming et al., 1987; Gilmore et al., 1995; Hill and Ralph, 2006).

There are many species and clades within the Symbiodinium taxon, and it is therefore likely that each symbiont could have different temperature susceptibilities. Species-specific resistance of zooxanthellate corals to varying levels of temperature stress may be the result of variability in heat-resistant Symbiodinium phytopigments. Corals less prone to bleaching exhibited much smaller changes in Symbiodinium carotenoid pigment concentrations. 
This set of pigments is responsible for photosynthate production and protection of Photosystems I and II. If zooxanthellar chl c and fucoxanthin pigments (both accessory pigments to chl a) become dysfunctional, the Symbiodinium cells may not be harmed by elevated temperatures in the short-term. Reduced concentrations of chl a, however, will harm it and therefore affect the symbiotic relationship.

\section{Conclusion}

It has been shown that the phytopigments of Symbiodinium are susceptible to disruption under conditions of elevated seawater temperatures. In addition, this susceptibility occurs in three different Indo-Pacific species of coral derived from three different families within the Scleractinia. Our results also suggest that a drop in phytopigment concentration in response to elevated temperatures may well be a general phenomenon occurring across the Scleractinia - at least on the Great Barrier Reef. This is consistent with results of parallel experiments indicating that the symbiont zooxanthellae are much more susceptible to temperature stress than their host counterparts (Sammarco \& Strychar, 2009). It also supports earlier findings that most of the adaptation to temperature in this symbiotic pairing is most likely occurring in the zooxanthellae, not the hosts, which are already adapted (or exapted) to high seawater temperatures. Secondly, our results suggest that, because of the observed variability between pigments within a species, and the interspecific variability observed between holobionts, the character of the specific responses of a phytopigment or group of phytopigments to elevated temperatures becomes difficult to predict.

\section{Acknowledgements}

We thank the Great Barrier Reef Marine Park Authority and the Zoological Society of New South Wales (Australia) for grants awarded to KBS, and the Centre for Land and Water, Central Queensland University, for additional assistance awarded to M. Coates, P.T. Scott, and T.J. Piva, supporting this project. Thanks to A. Lirette for assistance with graphics and to G. Muller-Parker for comments on an earlier draft of the manuscript.

\section{References}

Agustín, L-C. D. M., Laura, F-R., Sebastián, Z-S.J., Oscar, H-R., \& Carlos, L-C. (2006). Correlation of chlorophyll a and total carotenoid cencentrations with coral bleaching from locations on the Pacific coast of Mexico. Marine and Freshwater Behaviour and Physiology, 39, 279-291. http://dx.doi.org/10.1080/10236240600976580

American Public Health Association. (1989). Standard Methods for the Examination of water and Wastewater. 17th Edition. APHA

Apprill, A. M., Bidigare, R.R., \& Gates, R.D. (2007). Visibly healthy corals exhibit variable pigment concentrations and symbiont phenotypes. Coral Reefs, 26, 387-397. http://dx.doi.org/10.1007/s00338-007-0209-y

Arar, E. J. (1997). In vitro determination of Chlorophylls a, b, c1+c2, and phaeopigments in marine and freshwater algae by visible spectrophotometry. Method 446.0. National Exposure Research Laboratory, Office of Research and Development, U.S. Environmental Protection agency, Cincinnati, Ohio. 25 pp. [Online] Available: http://www.epa.gov/microbes/m446_0.pdf

Baird, A. H., \& Marshall, P. A. (2002). Mortality, growth and reproduction in scleractinian corals following bleaching on the Great Barrier Reef. Marine Ecology Progress Series, 237, 133-141. [Online] Available: http://www.int-res.com/articles/meps2002/237/m237p133.pdf

Baker, A. C. (2003). Flexibility and specificity in coral-algal symbioses: Diversity, ecology, and biogeography of Symbiodinium. Annual Review of Ecology Systematics, 34, 661-689. http://dx.doi.org/10.1146/annurev.ecolsys.34.011802.132417

Baker, A. C. (2004). Symbiont diversity on coral reefs and its relationship to bleaching resistance and resilience. In E. Rosenberg (Ed.). Coral health and disease (pp. 177-194). Springer Verlag, Berlin.

Baker, A. C., Starger, C.J., Mcclanahan, T.R., \& Glynn, P.W. (2004). Corals' adaptive response to climate change. Nature, 430, 741. http://dx.doi.org/10.1038/430741a

Banaszak, A. T., \& Lesser, M. P. (2009). Effects of solar ultraviolet radiation on coral reef organisms. Photochemical and Photobiological Sciences, 8, 1276-1294. http://dx.doi.org/10.1039/b902763g

Barlow, R., Stuart, V., Lutz, V., Sessions, H., Sathyendranath, S. et al. (2007). Seasonal pigment patterns of surface phytoplankton in the subtropical southern hemisphere. Deep-Sea Research, 54, 1687-1703. http://dx.doi.org/10.1016/j.dsr.2007.06.010 
Becker, G. B., Norman, J., Moholt-Siebert, M. (1990). Two sites of heat-induced damage to photosystem II. In M. Baltscheffsky (Ed.). Current research in photosynthesis, pp. 705-708. Kluwer Academic Publishers, Boston.

Brotas, V., Mendes, C. R., \& Cartaxana, P. (2007). Microphytobenthic biomass assessment by pigment analysis: comparison of spectrophotometry and High Performance Liquid Chromatography methods. Hydrobiology, 587, 19-24. http://dx.doi.org/10.1007/s10750-007-0680-z

Brown, B. E., Ambarsari, I., Warner, M. E., Fitt, W. K., Dunne, R. P. et al. (1999). Diurnal changes in photochemical efficiency and xanthophyll concentrations in shallow water reef corals: Evidence for photoinhibition and photoprotection. Coral Reefs, 18, 99-106. http://dx.doi.org/10.1007/s003380050163

Brüssow, H. (2007). The quest for food: a natural history of eating. Springer Scientific.

Chalker, B. E., \& Dunlap, W. C. (1982). Extraction and quantification of endosymbiotic algal pigments from reef-building corals. Proceedings of the $4^{\text {th }}$ International Coral Reef Symposium, Manila, 2, 45-50

Coles, S. L., \& Jokiel, P. L. (1977). Effects of temperature on photosynthesis and respiration in hermatypic corals. Marine Biology, 43, 209-216. http://dx.doi.org/10.1007/BF00402313

Cooper, T. F., \& Fabricius, K. E. (2011). Pigmentation of massive corals as a simple bioindicator for marine water quality. Marine Pollution Bulletin, in press. http://dx.doi.org/10.1016/j.marpolbul.2011.07.019

De Martino, A., Douady, D., Quinet-Szely, M., Rousseau, B., Crepineau, F. et al. (2000). The light-harvesting antenna of brown algae: highly homologous proteins encoded by a multigene family. European Journal of Biochemistry, 267, 5540-5549. http://dx.doi.org/10.1046/j.1432-1327.2000.01616.x

Demmig-Adams, B., \& Adams, W. W. III. (2000). Photosynthesis: harvesting sunlight safely. Nature, 403, 371-374. http://dx.doi.org/10.1038/35000315

Demming, B., Winter, K., Krueger, A., \& Czygan, F. C. (1987). Photoinhibition and zeaxanthin formation in intact leaves. Plant Physiology, 84, 17-24. www.plantphysiol.org/cgi/doi/10.1104/pp.110.159087.

Demming-Adams, B., Gilmore, A., \& Adams, W. W. I. (1996). In vivo functions of carotenoids in higher plants. Federation of American Societies for Experimental Biology Journal, 10, 403-412.

Dove, S., Ortiz, J. C., Enriquez, S., Fine, M., Fisher, P. et al. (2006). Response of holosymbiont pigments from the scleractinian coral Montipora monasteriata to short-term heat stress. Limnology and Oceanography, 51, 1149-1158. http://dx.doi.org/10.4319/lo.2006.51.2.1149

Dove, S. G., Lovell, C., Fine, M., Deckenback, J., Hoegh-Guldberg, O. et al. (2008). Host pigments: potential facilitators of photosynthesis in coral symbioses. Plant, Cell \& Environment, 31, 1523-1533. http://dx.doi.org/10.1111/j.1365-3040.2008.01852.x

Drew, E. A. (1972). The biology and physiology of algal-invertebrate symbioses. II. The density of symbiotic algal cells in a number of hermatypic hard corals and alcyonarians from various depths. Journal of Experimental Biology and Ecology, 9, 71-75. http://dx.doi.org/10.1016/0022-0981(72)90008-1

Fang, L. S., Liao, C. W., \& Liu, M. C. (1995). Pigment composition in different-colored scleractinian corals before and during the bleaching process. Zoological Studies, 34, 10-17

Ferrier-Pagés, C., Rottier, C., Beraud, E. \& Oren, L. (2010). Experimental assessment of the feeding effort of three scleractinian coral species during a thermal stress; Effect on the rates of photosynthesis. Journal of Experimental Marine Biology and Ecology, 390, 118-124. http://dx.doi.org/10.1016/j.jembe.2010.05.007

Fitt, W.K., McFarland, F.K., Warner, M.E., \& Chilcoat, G.C. (2000). Seasonal patterns of tissue biomass and densities of symbiotic dinoflagellates in reef corals and relation to coral bleaching. Limnology and Oceanography, 45, 677-85. http://dx.doi.org/10.4319/lo.2000.45.3.0677

Fitt, W. K., Spencer, H. J., Halas, J., White, M. W., \& Porter, J. W. (1993). Recovery of Montastrea annularis in the Florida Keys after the 1987 Caribbean bleaching event. Coral Reefs, 12, 57-64. http://dx.doi.org/10.1007/BF00302102

Flores-Ramírez, L. A., \& Liñán-Cabello, M. A. (2007). Relationships among thermal stress, bleaching and oxidative damage in the hermatypic coral, Pocillopora capitata. Comparative Biochemistry and Physiology, 146, 194-202. http://dx.doi.org/10.1016/j.cbpc.2006.09.008

Gilmore, A. M., Hazlett, T. L., \& Govindjee. (1995). Xanthophyll cycle dependent quenching of photosystem II chlorophyll a fluorescence: formation of a quenching complex with a short fluorescence lifetime. Proceedings of 
the National Academy of Science, USA, 92, 2273-2277. [Online] Available: http://www.pnas.org/content/92/6/2273.full.pdf

Goenaga, C., Vicente, V.P., \& Armstong, R.A. (1989). Bleaching induced mortalities in reef corals from La Parguera, Puerto Rico: A precursor of change in the community structure of coral reefs? Caribbean Journal of Science, 25, 59-65. [Online] Available: http://academic.uprm.edu/publications/cjs/VOL25/P059-065.pdf

Goodwin, T. W. (1980). The biochemistry of the carotenoids. Vol I. Plants. Chapman and Hall, London. http://dx.doi.org/10.1007/978-94-009-5860-9

Govindjee, \& Govindjee, R. (1974). Primary events in photosynthesis. Scientific American, 231, 68-82. [Online] Available: http://www.life.illinois.edu/govindjee/Electronic\%20Publications/1974/1974_Gov_RGov.pdf

Govindjee. (1975). Bioenergetics of photosynthesis. Academic Press, NY, USA.

Grottoli, A.G., Rodrigues, L.J., \& Palardy, J.E. (2006). Heterotrophic plasticity and resilience in bleached corals. Nature, 440, 1186-1189. http://dx.doi.org/10.1038/nature04565

Havaux, M. (1993). Characterization of thermal damage to the photosynthetic electron transport system in potato leaves. Plant Science, 94, 19-33. http://dx.doi.org/10.1016/0168-9452(93)90003-I

Hendry, G.A.F., \& Price, A.H. (1993). Stress indicators: chlorophylls and carotenoids. In G.A.F. Hendry GAF \& J.P. Grime (Eds.). Methods in comparative plant ecology (pp. 148-152). Chapman \& Hall, London

Hill, R., \& Ralph, P.J. (2006). Photosystem II heterogeneity of in hospite zooxanthellae in scleractinian corals exposed to bleaching conditions. Photochemistry and Photobiology, 82, 1577-1585. http://dx.doi.org/10.1562/2006-04-13-RA-871

Hoegh-Guldberg, O., \& Smith, G.J. (1989a). Influence of the population density of zooxanthellae and supply of ammonium on the biomass and metabolic characteristics of the reef corals Seriatopora hystrix and Stylophora pistillata. Marine Ecology Progress Series, 57, 173-186. [Online] Available: http://www.int-res.com/articles/meps/57/m057p173.pdf

Hoegh-Guldberg, O., \& Smith, G.J. (1989b). The effect of sudden changes in temperature, light and salinity on the population density and export of zooxanthallae from the reef corals Stylophora pistillata (Esper) and Seriatopra hystix (Dana). Journal of Experimental Marine Biology and Ecology, 129, $279-303$. http://dx.doi.org/10.1016/0022-0981(89)90109-3

Jeffrey, S.W., \& Humphrey, G.F. (1975). New spectrophotometric equations for determining chlorophylls a1, b1, $\mathrm{c} 1$ and $\mathrm{c} 2$ in higher plants, algae and natural phytoplankton. Biochemie und Physiologie der Pflanzen, 167, 191-194.

Jokiel, P.L., \& Coles, S.L. (1974). Effects of heated effluent on hermatypic corals at Kahe Point, Oahu. Pacific Science, 28, 1-18.

Jones, R., \& Yellowlees, D. (1997). Regulation and control of intracellular algae (= zooxanthallae) in hard corals. Philosophical Transactions of the Royal Society B: Biological Sciences, 352, $457-468$. http://dx.doi.org/10.1098/rstb.1997.0033

Jones, R.J. (1997). Zooxanthellae loss as a bioassay for assessing stress in corals. Marine Ecology Progress Series, 149, 163-171. http://dx.doi.org/10.3354/meps 149163

Jones, R.J., Hoegh-Guldberg, O., Larkum, A.W.D., \& Schreiber, U. (1998). Temperature-induced bleaching of corals begins with impairment of the $\mathrm{CO}_{2}$ fixation mechanism in zooxanthellae. Plant, Cell \& Environment, 21, 1219-1230. http://dx.doi.org/10.1046/j.1365-3040.1998.00345.x

Kleppel, G.S., Dodge, R.E., \& Reese, C.J. (1989). Changes in the pigmentation associated with the bleaching of stony corals. Limnology and Oceanography, 34, 1331-1335. [Online] Available: http://aslo.org/lo/toc/vol_34/issue_7/1331.pdf

Kuguru, B., Achituv, Y., Gruber, D.F., \& Tchernov, D. (2010). Photoacclimation mechanisms of corallimorpharians on coral reefs: Photosynthetic parameters of zooxanthellae and host cellular responses to variation in irradiance. Journal of Experimental Marine Biology and Ecology, 394, 53-62. http://dx.doi.org/10.1016/j.jembe.2010.07.007

LaJeunesse, T.C., Thornhill, D.J., Cox, E.F., et al. (2004). High diversity and host specificity observed among symbiotic dinoflagellates in reef coral communities from Hawaii. Coral Reefs, 23, 596-603. http://dx.doi.org/10.1007/s00338-004-0428-4 
Latasa, M., Bidigare, R. R., Ondrusek, M. E., \& Kennicutt, M. C. (1996). HPLC analysis of algal pigments: a comparison exercise among laboratories and recommendations for improved analytical performance. Marine Chemistry, 51, 315-324. http://dx.doi.org/10.1016/0304-4203(95)00056-9

Leletkin, V. A., \& Popova, L. I. (2005). Light absorption by carotenoid peridinin in zooxanthellae cells and setting down of hermatypic coral to depth. Journal of General Biology, 66, 251-257.

Lenz, J., \& Fritsche, P. (1980). The estimation of chlorophyll a in water samples: A comparative study on retention in a glass-fibre and membrane filter and on the reliability of two storage methods. Archiv für Hydrobiologie-Beiheft Ergebnisse der Limnologie, 14, 46-51.

Lesser, M. P., \& Farrell, J. H. (2004). Exposure to solar radiation increases damage to both host tissues and algal symbionts of corals during thermal stress. Coral Reefs, 23, 367-377. http://dx.doi.org/10.1007/s00338-004-0392-z

Liñán-Cabello, M. A., Flores-Ramírez, L., Zacarías-Salinas, J. S., Hernández-Rovelo, O., \& Lezama-Cervantes, C. (2006). Correlation of chlorophyll a and total carotenoid concentrations with coral bleaching from locations on the Pacific coast of Mexico. Marine Freshwater Behaviour and Physiology, 39, 279-291. http://dx.doi.org/10.1080/10236240600976580

Mantoura, R. F. C., \& Llewellyn, C. A. (1983). The rapid determination of algal chlorophyll and carotenoid pigments and their breakdown products in natural waters by revers-phase high performance liquid chromatography. Analytica Chimica Acta, 151, 297-314. http://dx.doi.org/10.1016/S0003-2670(00)80092-6

Marker, A. F. H., Nusch, E. A., Rai, H., \& Riemann, B. (1980). The measurement of photosynthetic pigments in freshwaters and standardization of methods: conclusions and recommendations. Archiv für Hydrobiologie-Beiheft Ergebnisse der Limnologie, 14, 91-106.

Marshall, P. A., \& Baird, A. H. (2000). Bleaching of corals on the Great Barrier Reef: differential susceptibilities among taxa. Coral Reefs, 19, 155-163. http://dx.doi.org/10.1007/s003380000086

Mobley, K. B., \& Gleason, D. F. (2003). The effect of light and heterotrophy on carotenoid concentrations in the Caribbean anemone Aiptasia pallida (Verrill). Marine Biology, 143, 629-637. $\mathrm{http}: / / \mathrm{dx}$. doi.org/10.1007/s00227-003-1123-7

Muscatine, L., Porter, J. W., \& Kaplan, I. R. (1989). Resource partitioning by reef corals as determined from stable isotope composition 1 delta-C-13 of zooxanthellae and animal tissue vs. depth. Marine Biology, 100, 185-193. http://dx.doi.org/10.1007/BF00391957

Olsen, V. A., \& Owens, I. P. F. (1998). Costly sexual signals: Are carotenoids rare, risky or required? Trends in Ecology \& Evolution, 13, 510-514. http://dx.doi.org/10.1016/S0169-5347(98)01484-0

Oswald, F., Schmitt, F., Leutenegger, A., Ivanchenko, S., D’Angelo, C. et al. (2007). Contributions of host and symbiont pigments to the coloration of reef corals. Federation of European Biochemical Societies Journal, 274, 1102-1122. http://dx.doi.org/10.1111/j.1742-4658.2007.05661.x

Peñuelas, J., \& Munné-Bosch, S. (2005). Isoprenoids: an evolutionary pool for photoprotection. Trends in Plant Science, 10, 166-168. http://dx.doi.org/10.1016/j.tplants.2005.02.005

Porra, R. J., Pfündel, E. E., \& Engel, N. (1997). Metabolism and function of photosynthetic pigments. In S.W Jeffery, R. F. C. Mantoura, \& S. W. Wright. (Eds.). Phytoplankton pigments in oceanography: Guidelines to modern methods (pp. 85-126). UNESCO, Paris.

Prezelin, B. B. (1981). Light reactions in photosynthesis. Canadian Journal of Fisheries and Aquatic Sciences, 210, 1-43. http://dx.doi.org/10.1038/npg.els.0001311

Ralph, P. J., Gademann, R., \& Larkum, A. W. D. (2001). Zooxanthellae expelled from bleached corals at $33^{\circ} \mathrm{C}$ are photosynthetically competent. Marine Ecology Progress Series, 220, 163-168. http://dx.doi.org/10.3354/meps220163

Reese, C. J., Kleppel, G. S., \& Dodge, R. E. (1988). The physiological implications of bleaching of corals off southeast Florida. Proceeding Association of Island Marine Laboratories of the Caribbean, 21, 66.

Riddle, D. (2007). Coral coloration, Part 6: Non-fluorescent chromoproteins (CP)-568-CP-610) and a newly discovered colorant. [Online] Available: ww.advancedaquarist.com/2007/7/aafeature1

Salih, A., Cox, G., Szymczak, R., Coles, S. L., Baird, A. H. et al. (2006). The role of host-based color and fluorescent pigments in photoprotection and in reducing bleaching stress in corals. Proceedings of the $10^{\text {th }}$ 
International Coral Reef Symposium, Okinawa, p 746-756. [Online] Available: http://www.coralcoe.org.au/research/publications/Salih_ICRS_2006.pdf

Salih, A., Larkum, A., Cox, G., Kühl, M., \& Hoegh-Guldberg, O. (2000). Fluorescent pigments in corals are photoprotective. Nature, 408, 850-853. http://dx.doi.org/10.1038/35048564

Sartory, D. P., \& Grobbelaar, J. U. (1984). Extraction of chlorophyll a from freshwater phytoplankton for spectrophotometric analysis. Hydrobiologia, 114, 177-187. http://dx.doi.org/10.1007/BF00031869

Schlichter, D. (1990). Coral host improves photosynthesis of endosymbiotic algae. Naturwissenschaften, 77, 447-450. http://dx.doi.org/10.1007/BF01135950

Seely, G. R., Cuncan, M. J., \& Vidaver, W. E. (1972). Preparative and analytical extraction of pigments from brown algae with dimethyl sulfoxide. Marine Biology, 12, 184-188. http://dx.doi.org/10.1007/BF00350754

Shenkar, N., Fine, M., Winter, E. K., \& Loya, Y. (2006). Population dynamics of zooxanthellae during a bacterial bleaching event. Coral Reefs, 25, 223-227. http://dx.doi.org/10.1007/s00338-006-0090-0

Shibata, K. (1969). Pigments and a UV-absorbing substance in corals and a blue-green algae living in the Great Barrier Reef. Plant, Cell \& Environment, 10, 325-335.

Smith, D. J., Suggett, D. J., \& Baker, N. R. (2005). Is photoinhibiton of zooxanthellae photosynthesis the primary cause of thermal induced bleaching in corals? Global Change Biology, 11, 1-11. http://dx.doi.org/10.1111/j.1365-2486.2004.00895.x

Sokal, R. R., \& Rohlf, F. J. (1981). Biometry. WH Freeman, San Francisco, USA.

Ston, J., \& Kosakowska, A. (2000). Qualitative and quantitative analysis of Baltic phytoplankton pigments. Oceanologia, 42, 449-471. [Online] Available: http://www.iopan.gda.pl/oceanologia/424Ston.pdf

Strychar, K. B. (2002). Bleaching in soft and scleractinian corals: Comparison of the physiology, genetics, and biochemistry of Symbiodinium. PhD dissertation, Central Queensland University, Rockhampton.

Strychar, K. B., \& Sammarco, P. W. (2009). Exaptation in corals to high seawater temperatures: Low concentrations of apoptotic and necrotic cells in host coral tissue under bleaching conditions. Journal of Experimental Marine Biology and Ecology, 369, 31-42. http://dx.doi.org/10.1016/j.jembe.2008.10.021

Strychar, K. B., Coates, M., \& Sammarco, P. W. (2004a). Loss of Symbiodinium from bleached Australian scleractinian corals (Acropora hyacinthus, Favites complanata and Porites solida). Marine \& Freshwater Research, 55, 135-144. http://dx.doi.org/10.1071/MF03080

Strychar, K. B., Coates, M., Sammarco, P. W., \& Piva, T. J. (2004b). Bleaching as a pathogenic response in scleractinian corals, evidenced by high concentrations of apoptotic and necrotic zooxanthellae. Journal of Experimental Marine Biology and Ecology, 304, 99-121. http://dx.doi.org/10.1016/j.jembe.2003.11.023

Strychar, K. B., Coates, M. C., Scott, P. W., Piva, T. J., \& Sammarco, P. W. (2005). Loss of symbiotic dinoflagellates (Symbiodinium; zooxanthellae) from bleached soft corals Sarcophyton, Sinularia and Xenia. Journal of Experimental Marine Biology and Ecology, 320, $159-177$. http://dx.doi.org/10.1016/j.jembe.2004.12.039

Tchernov, D., Gorbunov, M. Y., de Vargas, C., Yadav, S. W., Milligan, A. J. et al. (2004). Membrane lipids of symbiotic algae are diagnostic of sensitivity to thermal bleaching in corals. Proceedings of the National Academy of Science, 101, 13531-13535. http://dx.doi.org/10.1073/pnas.0402907101

Thebud, R., \& Santarius, K. A. (1982). Effects of high temperature on various biomembranes of leaf cells in situ and in vitro. Plant Physiology, 70, 200-205.

Venn, A. A., Wilson, M. A., Trapido-rosenthal, H. G., Keely, B. J., \& Douglas, A.E. (2006). The impact of coral bleaching on the pigment profile of the symbiotic alga, Symbiodinium. Plant, Cell \& Environment, 29, $2133-2142$. http://dx.doi.org/10.1111/j.1365-3040.2006.001587.x

Warner, M. E., Fitt, W. K., \& Schmidt, G. W. (1996). The effects of elevated temperature on the photosynthetic efficiency of zooxanthellae in hospite from four different species of reef coral: A novel approach. Plant, Cell \& Environment, 19, 291-299. http://dx.doi.org/10.1111/j.1365-3040.1996.tb00251.x

Warner, M. E., Fitt, W. K., \& Schmidt, G. W. (1999). Damage to photosystem II in symbiotic dinoflagellates: A determinant of coral bleaching. Proceedings of the National Academy of Science, 96, 8007-8012. http://dx.doi.org/10.1073/pnas.96.14.8007 
Wooldridge, S., Done, T., Berkelmans, R., Jones, R., \& Marshall, P. (2005). Precursors for resilience in coral communities in a warming climate: A belief network approach. Marine Ecology Progress Series, 222, $209-216$. http://dx.doi.org/10.3354/meps295157

Zhang, H., Bahttacharya, D., \& Lin, S. (2005). Phylogeny of dinoflagellates based on mitochondrial cytochrome $\mathrm{B}$ and nuclear small subunit rDNA sequence comparisons. Journal of Phycology, 41, 411-420. http://dx.doi.org/10.1111/j.1529-8817.2005.04168.x

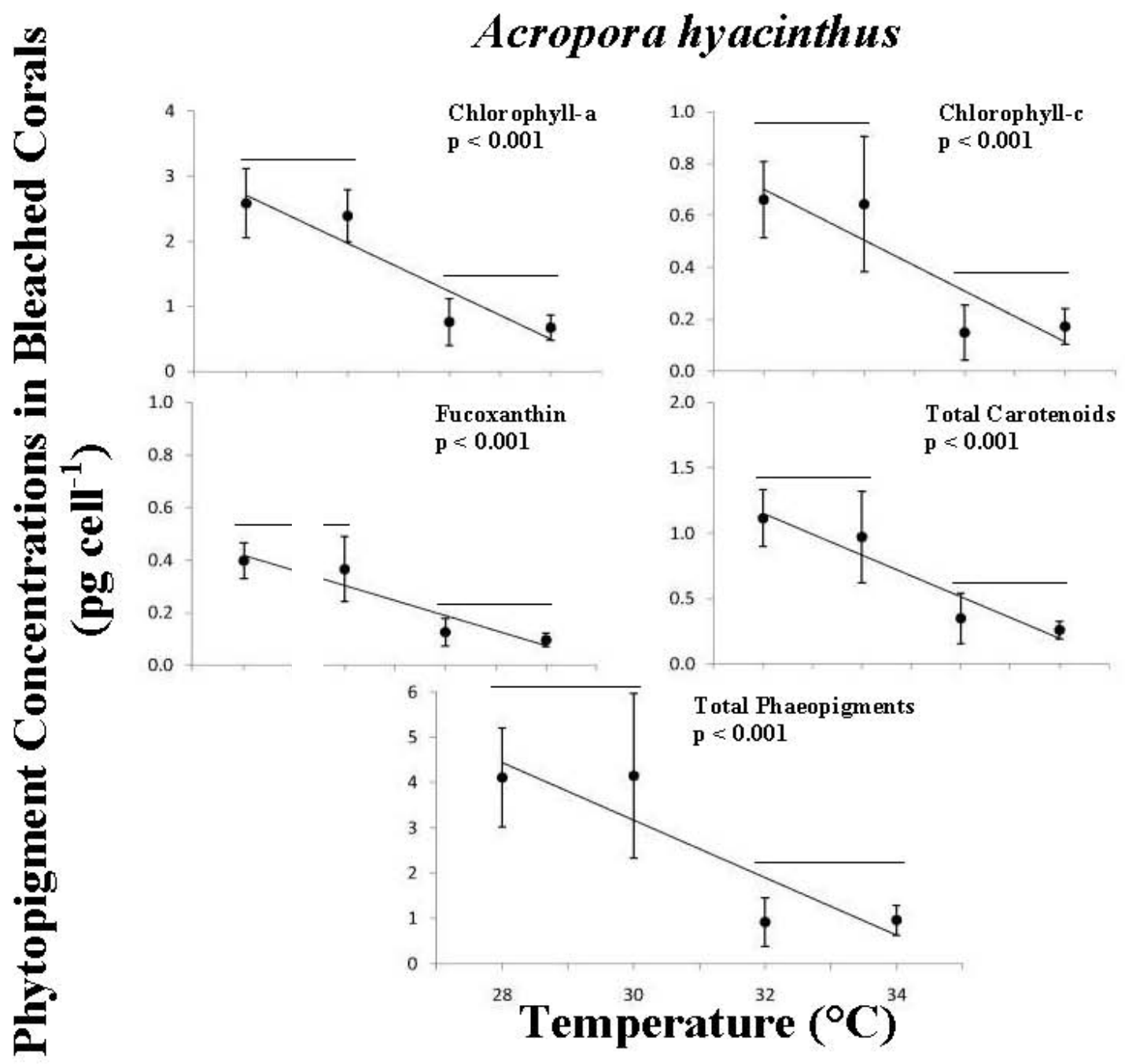

Figure 1. Acropora hyacinthus

Effect of temperature on phytopigment concentrations in zooxanthellae in situ under varying experimental temperatures: $28^{\circ} \mathrm{C}$ (control), $30^{\circ} \mathrm{C}, 32^{\circ} \mathrm{C}$, and $34^{\circ} \mathrm{C}$. Data presented as mean plus $95 \%$ confidence intervals. See Materials and Methods for experimental design. $\mathrm{n}_{\mathrm{t}}=10$ readings/temperature. Data shown for chlorophyll a, chlorophyll c, fucoxanthins, total carotenoids, and total phaeopigments. Significant differences between temperatures in all phytopigments $\left(\mathrm{p}<0.001\right.$, two-way nested ANOVA). Pigment concentrations for $28^{\circ} \mathrm{C}$ and $30^{\circ} \mathrm{C}$ were both significantly different from $32^{\circ} \mathrm{C}$ and $34^{\circ} \mathrm{C}$ in all pigments $(\mathrm{p}<0.05, \mathrm{~T}, \mathrm{~T}-\mathrm{K}$, and GT2 $a$ posteriori multiple comparisons techniques). Grouping of non-significant means indicated by horizontal line over the points. Pytopigment concentrations (excluding fucoxanthins) decreased in a significantly linear manner with temperature (e.g. carotenoids; $\mathrm{p}<0.05, \mathrm{y}=5.6111-0.1593 \mathrm{x}$ ). Scaling on Y-axes standardized within pigments and between graphs to facilitate comparisons between related figures. 


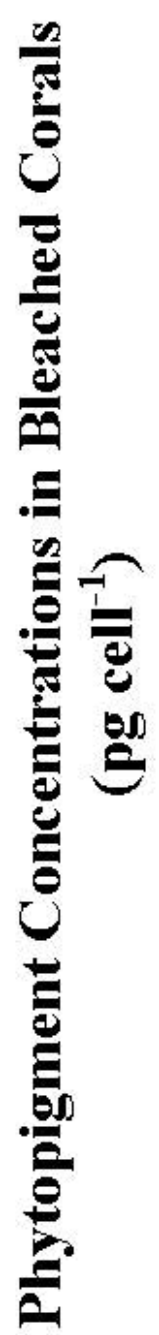

\section{Porites solida}

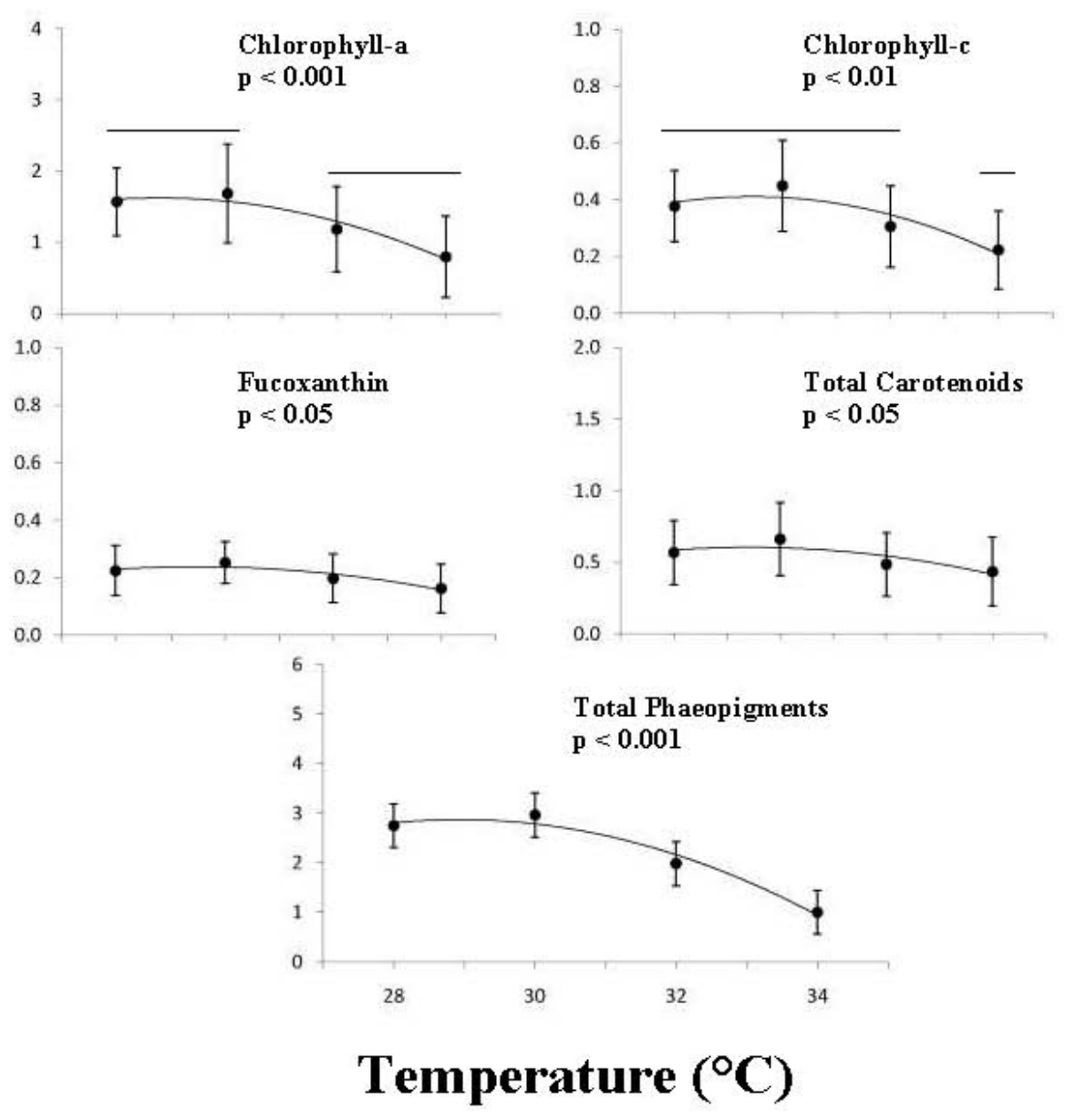

Figure 2. Porites solida

Effect of temperature on phytopigment concentrations in zooxanthellae in situ under varying experimental temperatures $-28^{\circ} \mathrm{C}$ (control), $30^{\circ} \mathrm{C}, 32^{\circ} \mathrm{C}$, and $34^{\circ} \mathrm{C}$. Significant difference between all temperatures for all pigments $(p<0.05-0.001$, ANOVA), except for total carotenoids $(p>0.05)$. Significant differences between temperatures in chl a concentrations ( $\mathrm{p}<0.001$, ANOVA); significant differences between $\left[28^{\circ} \mathrm{C}\right.$ and $\left.30^{\circ} \mathrm{C}\right] v s$. $\left[32^{\circ} \mathrm{C}\right.$ and $\left.34^{\circ} \mathrm{C}\right]$ via $\mathrm{T}^{\prime}, \mathrm{T}-\mathrm{K}$, and GT2 a posteriori tests $(\mathrm{p}<0.05) . \mathrm{Chl} \mathrm{c}-$ significant difference between temperatures ( $\mathrm{p}<0.001$, two-way ANOVA), with a significant difference between $\left[28^{\circ} \mathrm{C}, 30^{\circ} \mathrm{C}\right.$, and $\left.32^{\circ} \mathrm{C}\right] v s$. $34^{\circ} \mathrm{C}$, a posteriori tests, $\mathrm{p}<0.05$ ); relationship best described by significant second degree polynomial regression $\left(\mathrm{p}<0.001, \mathrm{Y}=-0.0486 \mathrm{x}^{2}+2.8583 \mathrm{x}-40.0014\right.$; fucoxanthins $(\mathrm{p}<0.05$, two-way ANOVA; significant differences between individual means ( $\mathrm{p}<0.05$, a posteriori tests - as above; see text for discussion). Carotenoids (excluding fucoxanthins), no significant difference in phytopigment concentrations between experimental temperatures ( $\mathrm{p}>0.05$, two-way ANOVA). Total phaeophytins, significant difference between experimental temperatures $(\mathrm{p}<0.001$, two-way ANOVA); significant differences between individual means $(\mathrm{p}<$ 0.05 , a posteriori tests). See Figure 1 legend for additional details. 


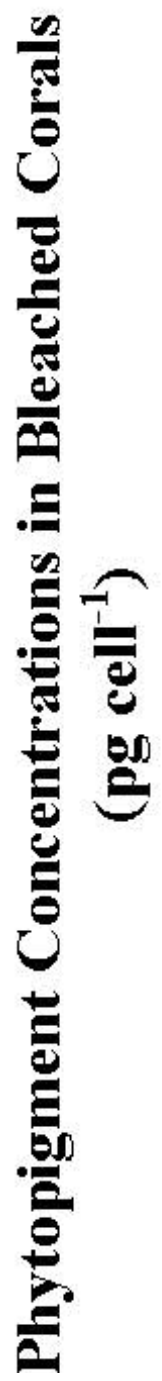

\section{Favites complanata}
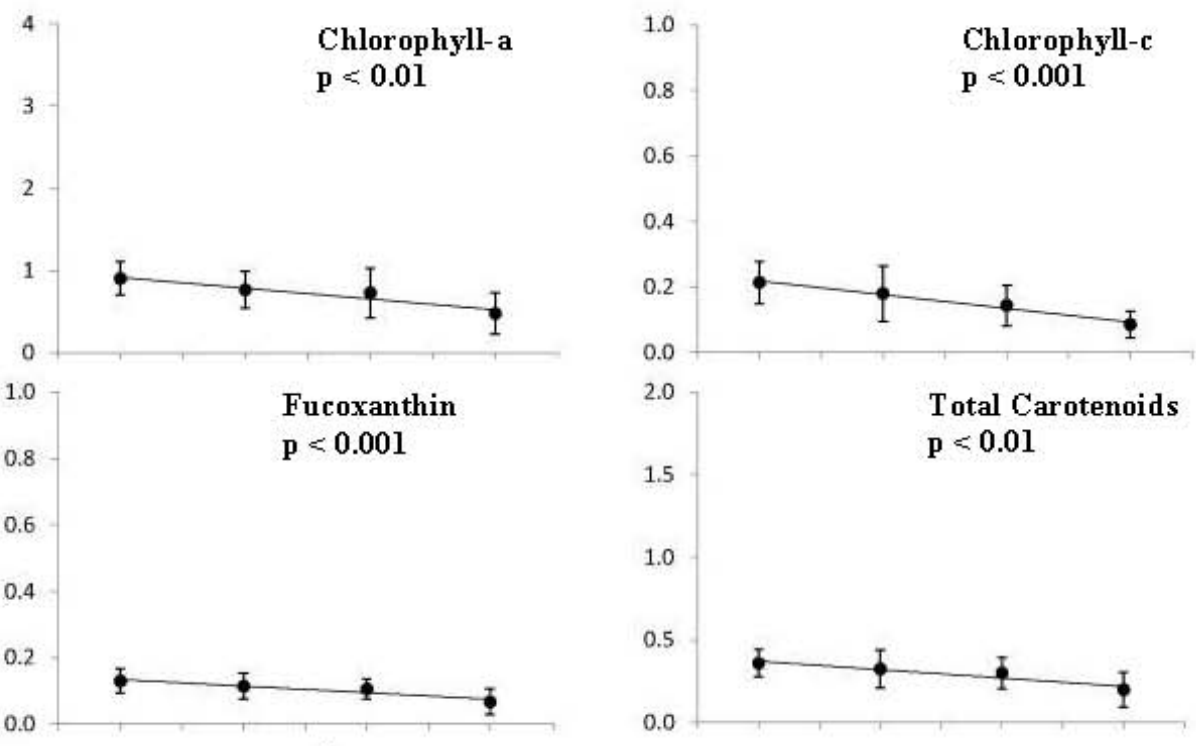

Total Phaeopigments $\mathrm{p}<0.05$

Figure 3. Favites complanata

Effect of temperature on phytopigment concentrations in zooxanthellae in situ under varying experimental temperatures $-28^{\circ} \mathrm{C}$ (control), $30^{\circ} \mathrm{C}, 32^{\circ} \mathrm{C}$, and $34^{\circ} \mathrm{C}$. Data presented as mean plus $95 \%$ confidence intervals. Highly significant difference between all temperatures for chl-a, chl-c, fucoxanthins, and total carotenoids. Significant negative relationship found between temperature and phytopigment concentration via least squares linear regression in all phytopigments: $\mathrm{Chl} a(\mathrm{p}<0.01$, ANOVA; $\mathrm{p}<0.05$, linear regression, $\mathrm{Y}=15.142-0.361$ $\mathrm{x})$; chl c $(\mathrm{p}<0.01$, ANOVA; $\mathrm{p}<0.01$, linear regression, $\mathrm{Y}=4.429-0.115 \mathrm{x})$; fucoxanthins, $(\mathrm{p}<0.05$, ANOVA; $\mathrm{p}<0.05$, linear regression, $\mathrm{Y}=2.261-0.054 \mathrm{x})$; carotenoids, excluding fucoxanthins, $(\mathrm{p}<0.01$, ANOVA; $\mathrm{p}<$ 0.05 , linear regression, $\mathrm{Y}=5.949-0.140)$; and phaeophytins $(\mathrm{p}<0.05$, linear regression, $\mathrm{Y}=29.721-0.709 \mathrm{x})$. See legend of Figure 1 for additional details. 


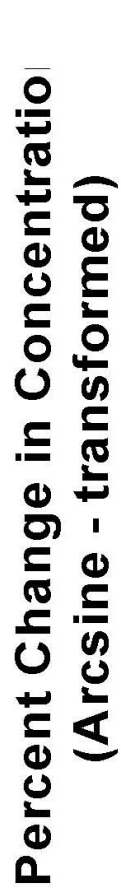

Acropora hyacinthus

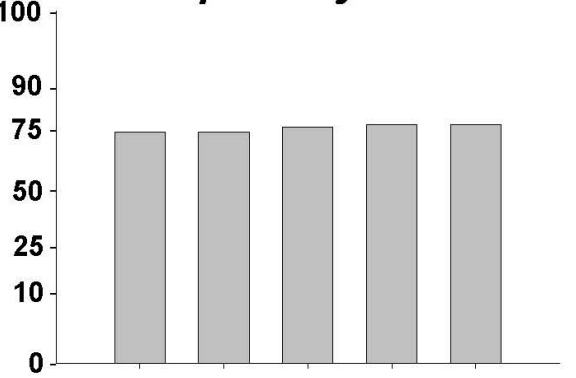

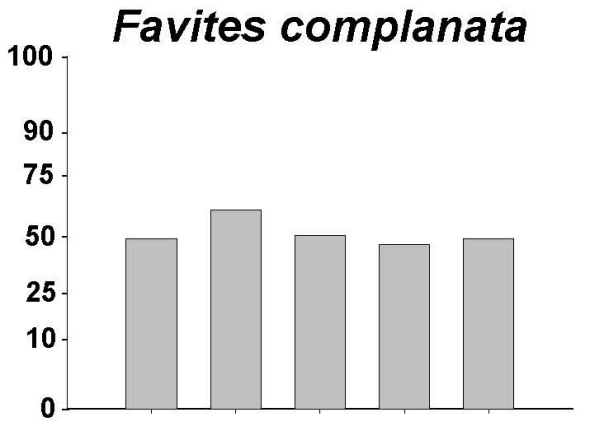

Porites solida

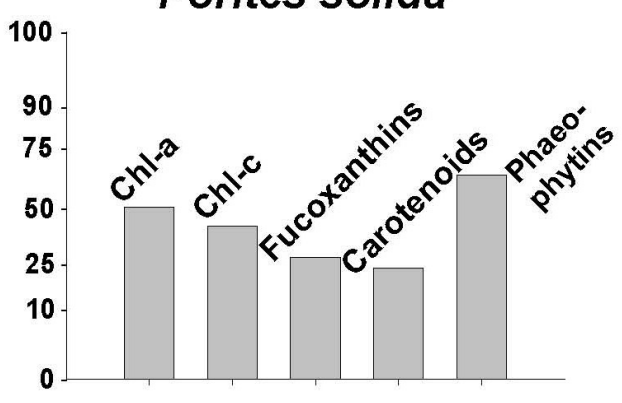

Pigments

Figure 4. Species-specific proportional changes in pigment concentrations between three zooxanthellate scleractinian corals, under experimentally elevated seawater temperatures

Data represent final average pigment concentrations after exposure to a maximum experimental temperature of $34^{\circ} \mathrm{C}$ for $48 \mathrm{~h}$ divided by average initial concentration at $28^{\circ} \mathrm{C}$ (control). Percent changes shown for chl a, chl c, fucoxanthins, total carotenoids, and total phaeophytins. Data transformed by arcsine for purposes of normalization. $\mathrm{n}_{\mathrm{i}}=10$. Note that the zooxanthellar pigments within Acropora hyacinthus decreased at approximately the same rate, while chl $\mathrm{c}$ was depleted faster than all other pigments in Favites complanata. All zooxanthellar pigments changed at different rates in Porites solida. 